\title{
The Rise and Fall of German Productivity \\ Software Investment as the Decisive Driver*
}

\author{
Theo S. Eicher \\ Department of Economics, University of Washington \\ Ifo Institute for Economic Research at the University of Munich \\ Thomas Strobel \\ Ifo Institute for Economic Research at the University of Munich \\ Department of Economics, University of Munich
}

June, 2007

\begin{abstract}
Investments in Information and Communication Technology (ICT) are the source of the global growth resurgence that commenced in the mid 1990s. Most studies focus on broad ICT measures, or on computer hardware; here we examine the contributions of software intensive industries to productivity growth. The price of prepackaged software has been falling exponentially since the 1960 s, which has led to substitutions towards software investments, and to reductions in the total cost of ICT hardware investments. We use novel German ICT investment data to show that software intensive industries have been the crucial determinant of German productivity growth since 1995 . Not only did these industries contribute strongly to productivity growth, but they offset declining investments and productivities in other industries. Post 1995 other industries' investments in new equipment per worker collapsed, while software intensive industries' capital investments rose steadily to generate over half of Germany's productivity growth by 2000-2004. We document sharply diverging productivity paths for software intensive and other industries. Post 1991, total factor productivity (TFP) declined secularly in other industries to generate a $15 \%$ drag on German labor productivity, while TFP in software intensive industries rose steadily to contribute 35\% to German labor productivity growth by 2000-2004. Overall the results combine to paint a stark picture of rising capital per worker and TFP growth in software intensive sectors, contrasting with falling capital per worker and increasingly negative TFP growth in non software intensive sectors. Two thirds of the impact from software intensive industries is generated by investments in prepackaged software.
\end{abstract}

JEL Classification: O3, O4

Keywords: Software Intensive Industries and Productivity Growth, Industry Productivity Analysis, Growth Accounting.

* We thank Vivek Ghosal and participants at the CESifo Economic Studies Conference on Productivity and Growth in Munich, Germany, June 22- 23, 2007 for helpful comments. We also thank Elke Kronjäger for sharing industrylevel, asset-specific ifo investment data, and the German Science Foundation (grant \#524685) for financial support. 


\section{Introduction}

The wealth of nations is ultimately determined by productivity growth. More productive workers experience higher living standards because increased efficiency allows for greater income and/or leisure. Examining the economic history of mankind in the Handbook of Economic Growth, Oded Galor (2005) points out that productivity increases ended the epoch of Malthusian stagnation in the 1700s and subsequently generated for sustained economic

growth. Productivity is also universally acknowledged as the source of the unprecedented rise in human welfare in the past century, when living standards increased six-fold in the US and Germany.

Productivity increases have not been constant. Lackluster growth in the 1970s saw a decline in productivity growth to about two-thirds of its pace in the previous 50 years. Starting about 1995, however, the US economy productivity growth accelerated again and unemployment fell to levels not seen since the 1960s. Jorgenson (2005) argues that the magnitude of the American growth resurgence outpaced all but the most optimistic expectations. After advances in the productivity measurement allowed for effective accounting of information technology in national statistics (Schreyer, 2001), it became clear that the recent productivity increases originated with Information and Communication Technology (ICT) investments. The novel characteristics of ICT driven economies led to the coinage of the term the "New Economy."

The hallmark of the New Economy - faster, better, cheaper - is reflected in the dramatic decline of ICT prices (Jorgenson 2005). Here the focus of ICT studies has generally been on the price of computers, since the foundation of ICT innovations is often thought to originate with tangible hardware improvements (e.g., Moore’s Law; Moore, 1965). In this paper we take an alternate view. Instead of focusing on the hardware and equipment side of ICT, we examine the software side, which is the interface that ultimately translates computing power into productivity increases.

The US Bureau of Economic Analysis (Grimm, 1998) first reported rapidly falling prices of computing, but did not recognize software as an investment good in its National Income Product Accounts until 1999 (it was previously classified as "intermediate consumption“). Most European statistical offices do not provide actual statistics for software as an investment good, although the OECD does provide software investment estimates (see Ahmad, 2003). Jorgenson and Stiroh (2000b) contend that the initial ICT prices in the national accounts seriously underestimate the quality adjusted change in software and 
communications technology prices. They developed new hedonic price indices, which then highlighted the dramatic decline in these two ICT components' costs to manufacturers (see Figure 1).

While the fall in computing prices and the rise in computing power are well documented, the dramatic decline in software prices and the associated increase in functionality is often not the explicit focus of productivity analyses. However, swiftly falling software prices provide not only added economic incentives to adopt new software, they also reduce the quality adjusted cost of existing and new ICT hardware. This leads to an accelerated substitution of all forms of ICT investment for other capital and labor services. Software price declines thus have a doubly enabling effect: first is the increase in the productivity of hardware and second is the elevated efficiency of workers using hardware with a more efficient interface. Finally, while computer and communication investments might constitute the lions' share of the expenses of ICT capital investment, the value added share attributed to software is about twice the size of computing and communication combined (Figure 2). ${ }^{1}$ We see this as yet another reason to motivate a thorough analysis of software investment as a determinant of the productivity fortunes of nations.

In this paper we focus on software investment in Germany. A unique dataset has become available in form of the Ifo Institute Industry Productivity Growth Database that provides detailed accounts of software investments dating back to the early 1990s. ${ }^{2}$ The data is based on annual direct survey responses from a representative sample of German industries. In most other countries, software investments are extrapolated; even the official German national accounts do not report actual software investment data. The German Statistical office extrapolates data back to 1991, based on ifo Institute data from 1995 and 1996 (see OECD, 2000, p 16). The Ifo Industry Productivity Growth Database provides actual data information for unified Germany with information on industry-level value added, investment, capital stocks and services, and quality adjusted labor hours for 52 German industries and 12 different assets from 1991 to 2004. The 52 industries span the entire German economy (with the exception of household services).

The Ifo Industry Growth Accounting Database has three unique features. First, it provides information on an unusually large number of capital stocks and capital services at

\footnotetext{
${ }^{1}$ Value added is a measure of output that represents revenue minus the non-labor costs of inputs.

${ }^{2}$ A full description and documentation of the data is available in Roehn et al. (2007) and the data is available at faculty.washington.edu/te/growthaccounting.
} 
the industry-level. Second, the industry-level assets include three different ICT asset types: computer and office equipment, communication equipment, and software. Among these, software is of particular interest in this paper to illuminate the German productivity performance in the past decade. Third, the detailed disaggregation of the different asset types and marginal productivities (measured as user costs) in the database allows us to construct the most accurate measures of software and non software capital services.

Our dataset allows us to separate industries into software intensive and non software intensive industries. Here we follow a broad literature that established categories for ICTIntensive and non ICT intensive industries by using the capital shares. In our case, we use the most traditional measure (Stiroh and Botsch, 2007) and identify those industries as software intensive whose software capital depth (software capital per hours worked) exceed the median. $^{3}$ Table 1 reports all industries and their software intensity classification. It highlights the importance of software depth as our selection criterion. It is not the absolute amount of software investment or capital that matters, the effect of software is crucially moderated by the number of employees relative to that investment. The measure thus provides a clear avenue for productivity improvements, not only from software capital investment alone, but from the increased productivity per worker in a given industry.

Similar data on ICT investment is available at the Groningen Growth and Development Centre, which focuses on international productivity comparisons. Differences between the Ifo Industry Growth Accounting Database and the Groningen Industry Growth Accounting Database are discussed in Eicher and Roehn (2007). Important for our purposes is that Groningen reports 26 industries, while Eicher and Roehn (2007) report data for 52 industries. Most importantly, however, German software investments are not reported by the German Statistical Office. The Groningen database assumes that software investment can be "split off from total intangible investment at the aggregate level by using the average corresponding share from France, Finland and Italy." (Inklaar et al 2003). Groningen then generates German industry-level software investment by using a ratio of software to ICT equipment investment that was obtained from an average of French, Dutch and US data.

Instead, the Ifo Industry Growth Accounting Database obtains data on software investment shares in total intangible assets, and industry-level software investment from a ifo

\footnotetext{
${ }^{3}$ See, for example, Skoczylas and Tissot (2005) and Stiroh and Botsch (2007). Alternative specifications of software intensity could focus on software capital shares, see, for example, Stiroh (2002), Jorgenson, Ho, Stiroh (2005b), and Triplett and Bosworth (2004).
} 
Institute study by Herrmann and Mueller (1997), and from surveys conducted by the Ifo Investment Survey. ${ }^{4}$ As detailed in Herrmann and Mueller (1997), the software estimates are based on specific questions that solicited information on industry-level investment in prepackaged and own account software in 1995, 1998, 1999 and 2000. The Ifo surveys yielded results that allowed the disaggregation of software investments into own account and prepackaged software, implying that a stable $75 \%$ of German software investment is comprised of prepackaged software across sectors and time.

Our results show that software intensive industries are a crucial determinant of German productivity growth from 1991 to 2004. Not only did they contribute strongly to productivity growth, but they also offset declining investments in other industries. From 1991-1995, investment in new equipment that increased “capital deepening” (the amount of capital per worker) was about identical in software intensive and non software intensive industries. Thereafter capital deepening in non software intensive industries collapsed to contribute only a fraction to German labor productivity growth, while investment in software intensive industries expanded to generate over half (!) of Germany's productivity growth from 20002004.

Results are even more dramatic in terms of total factor productivity (TFP) growth, which is the portion of output growth that is commonly attributed to technical change. The overall contribution of TFP to labor productivity growth has been puzzlingly low in Germany. We resolve the puzzle and show that the reasons for this low contribution lies in the diverging paths that software and non software intensive industries have taken since 1991. TFP declined consistently in non software intensive industries to generate about a $15 \%$ drag on German labor productivity, while TFP rose steadily in software intensive industries to generate an astonishing 35\% contribution to labor productivity growth between 2000-2004. Overall the results combine to provide a clear picture of rising capital deepening and TFP growth in software intensive sectors, contrasting with falling capital deepening and increasingly negative TFP growth in non software intensive sectors.

Formal econometric tests of the differential growth rates in (non-)software intensive industries to labor productivity growth are even more revealing. Pre 1995, the mean growth rate of software intensive industries is already one percentage point greater than non software

\footnotetext{
${ }^{4}$ The Ifo Investment Survey follows the EU guidelines for harmonized business surveys and contains 70,000 German firms, 5000 of which are surveyed for each sample period. It is established as an excellent leading indicator of German investment; it is also incorporated in a number of other leading indicators, most prominently the European Commission's Economic Indicators of the Euro Zone.
} 
intensive industries. Post 1995, German industries experience a dramatic bifurcation. Labor productivity in non software intensive industries declines in excess of one percentage point. In sharp contrast, labor productivity in software intensive industries accelerated by another 1.5 percentage points to a strong $5 \%$ growth rate. The acceleration was not uniform across software intensive industries. The median change in labor productivity among software intensive industries was actually negative. Much of the growth was driven by above median software intensive industries that saw growth increases of about $10 \%$.

The paper is organized as follows: Section 2.1 gives a brief overview of the underlying growth accounting methodology in the Ifo Industry Growth Accounting Database and Section 2.2 discusses the resulting contributions of software and non software intensive industries to productivity growth. Section 3 provides the econometric framework to estimate the influence of software intensity productivity. Section 4 concludes.

\section{Deriving Industry Contributions to Labor Productivity Growth}

\subsection{Methodology}

Our methodology to disentangle the various contributions in German labor productivity growth follows Eicher and Roehn (2007), who outline the German growth accounting paradigm for the Ifo Industry Growth Accounting Database. Industry contributions to aggregate productivity are calculated using the Jorgenson, Gallop and Fraumeni (1987) productivity framework that is commonly applied in most productivity studies. ${ }^{5}$ Industrylevel gross output growth are then decomposed into input and TFP contributions according to

$$
\Delta \ln Y_{i}=\bar{v}_{K, i}^{S O F T} \Delta \ln K_{i}^{S O F T}+\bar{v}_{K, i}^{N O N} \Delta \ln K_{i}^{N O N}+\bar{v}_{L, i} \Delta \ln L_{i}+\bar{v}_{X, i} \Delta \ln X_{i}+T F P_{i},
$$

where $Y_{i}$ is gross output for industry $i, K_{i}^{\text {SOFT }}$ are software capital services, $K_{i}^{N O N}$ are non software capital services, $L_{i}$ represents labor services, and $X_{i}$ are intermediate inputs. The $\bar{v}$ 's are two-period averaged nominal input shares. Labor services are defined as $\Delta \ln L_{i}=\sum_{j} \bar{\omega}_{j, i} \Delta \ln H_{j, i}$, where $H_{j, i}$ are hours worked of labor (skill) type $j$ in industry $i$ and $\bar{\omega}_{j, i}$ is the two-period averaged compensation share of labor type $j$ in total labor compensation of industry $i$.

To relate industry gross output growth to value added output growth we rewrite (1) as

\footnotetext{
${ }^{5}$ For recent industry studies that apply this method, see, for example, Jorgenson, Ho and Stiroh (2005a), Jorgenson, Ho, Samuels and Stiroh (2006) and Inklaar, O’Mahony and Timmer (2005).
} 


$$
\Delta \ln Y_{i}=\bar{v}_{V, i} \Delta \ln V_{i}+\bar{v}_{X, i} \Delta X_{i},
$$

where $V_{i}$ is value added and $\bar{v}_{V, i}$ is the nominal share of value added in gross output of industry $i$. Combining equations (1) and (2), yields industry value added growth

$$
\Delta \ln V_{i}=\frac{\bar{v}_{K, i}^{S O F T}}{\bar{v}_{V, i}} \Delta \ln K_{i}^{S O F T}+\frac{\bar{v}_{K, i}^{N O N}}{\bar{v}_{V, i}} \Delta \ln K_{i}^{N O N}+\frac{\bar{v}_{L, i}}{\bar{v}_{V, i}} \Delta \ln L_{i}+\frac{1}{\bar{v}_{V, i}} T F P_{i} .
$$

Defining aggregate output as the weighted average of industry value added, $\Delta \ln V \equiv \sum_{i} \bar{w}_{i} \Delta \ln V_{i}$, and $\bar{w}_{i}$ as the average share of industry value added in aggregate value added, we can combine this expression with (3) to obtain

$$
\Delta \ln V=\sum_{i} \bar{w}_{i}\left(\frac{\bar{v}_{K, i}^{S O F T}}{\bar{v}_{V, i}} \Delta \ln K_{i}^{S O F T}+\frac{\bar{v}_{K, i}^{N O N}}{\bar{v}_{V, i}} \Delta \ln K_{i}^{N O N}+\frac{\bar{v}_{L, i}}{\bar{v}_{V, i}} \Delta \ln L_{i}+\frac{1}{\bar{v}_{V, i}} \Delta \ln T F P_{i}\right) .
$$

Note that $\left(\bar{w}_{i} \Delta \ln T F P_{i}\right) / \bar{v}_{V, i}$ represents the "Domar-weighted" industry-level TFP growth where the "Domar-weights" are given by the quotient of the share of industry value added in aggregate value added, and the share of industry value added in industry gross output.

We are interested specifically in the industry contributions to average labor productivity, $V / H$, where $H$ is the unweighted sum of industry hours, $H_{i}=\sum_{j} H_{j, i}$, over all $j$ labor types. The growth rate of labor productivity is then $\Delta \ln A L P=\Delta \ln V-\Delta \ln H$, which yields after substituting for value added in (4)

$$
\Delta \ln A L P=\sum_{i} \bar{w}_{i} \Delta \ln A L P_{i}+\left(\sum_{i} \bar{w}_{i} \Delta \ln H_{i}-\Delta \ln H\right)=\sum_{i} \bar{w}_{i} \Delta \ln A L P_{i}+R^{H}
$$

The first term on the right hand side represents direct industry contributions to APL growth and $R^{H}$ reflects the reallocation of hours. ${ }^{6}$ Defining $\Delta \ln k_{i}^{S O F T}, \Delta \ln k_{i}^{N O N}$, and $\Delta \ln q_{i}$ as software capital deepening, non software capital deepening and labor quality growth, (4) and (5) yield

$\Delta \ln A L P=\sum_{i} \bar{w}_{i}\left(\frac{\bar{v}_{K, i}^{S O F T}}{\bar{v}_{V, i}} \Delta \ln k_{i}^{S O F T}+\frac{\bar{v}_{K, i}^{N O N}}{\bar{v}_{V, i}} \Delta \ln k_{i}^{N O N}+\frac{\bar{v}_{L, i}}{\bar{v}_{V, i}} \Delta \ln q_{i}+\frac{1}{\bar{v}_{V, i}} \Delta \ln T F P_{i}\right)+R^{H}$,

where $\Delta \ln q_{i}=\Delta \ln L_{i}-\Delta \ln H_{i}=\sum_{j} \bar{\omega}_{j, i} \Delta \ln H_{j, i}-\Delta \ln H_{i} \quad$ is the growth rate of labor

\footnotetext{
${ }^{6}$ The contribution of an industry to aggregate reallocation of hours is positive if an industry with an ALP level above (below) the aggregate average level experiences positive (negative) growth in hours.
} 
quality. The APL decomposition in (6) has the advantage that input contributions or TFP contributions to APL from any industry subset simply equal the (weighted) sum of the contributions from all industries in the subset.

\subsection{Contribution of Software to Productivity Growth}

To measure productivity, we examine labor productivity growth that is averaged over the periods 1991-1995, 1995-2000, 2000-2004. 1991 is the earliest data available for Germany, and 2004 is the latest industry output data available from the German Statistical Office. Averaging is standard to account for cyclical productivity fluctuations, and the time intervals are chosen to coincide with well documented trend breaks in the US productivity data.

Labor productivity can be decomposed into four components: changes in 1) hours worked, 2) labor quality, 3) capital deepening (the increase in the amount and quality of capital available to workers), and 4) total factor productivity (productivity increases in all other factors that increase the productivity of labor). Capital deepening and total factor productivity can be disaggregated further into contributions from software intensive industries and non software intensive industries. Table 2 displays the growth accounting results for the three sample periods. First we note that German productivity has been in decline since 1991. This decline has been attributed to a lack of ICT investment (Eicher and Roehn, 2007). In the US, strong ICT investments more than offset the reductions in non-ICT capital deepening and total factor productivity in the US (Stiroh and Botsch 2007).

Table 2 isolates the contributions from the four broad sources of productivity growth. By far the largest contribution is derived from capital deepening. From 1991-2000, 44\% of German labor productivity growth was generated by additional capital services that raised the productivity of the labor force. Post 2000, this share increased to 67\%. Among industries that increased labor productivity though capital investment, we can distinguish the contributions from software intensive and other industries. In 1991-1995 the capital deepening contributions of the two types of industries was about equal, 23\% vs. $21 \%$ for software intensive and other industries, respectively. However, post 1995, a bifurcation commences where software intensive industries began to increase their capital deepening dramatically to contribute ever more strongly to labor productivity growth (rising to 53\% in 2000-2004). Capital deepening in software intensive industries declined over the same period to a mere $15 \%$. The important contribution of capital deepening to German labor productivity growth is thus not only driven by software intensive industries capital investment and capital 
deepening, but these industries actually offset the decline of non software intensive industries between 1991 and 2004.

The second important category of productivity determinants is TFP, which is the portion of output growth not explained changes in the quantity of inputs used in production. It is often directly associated with technical change, but it may also capture changes in market structure or capacity utilization. Endogenous growth models in the 1990s link TFP growth rates directly to innovation. Specifically, $R \& D$ subsidies and an abundance of skilled labor are shown to reduce the marginal cost of conducting $R \& D$ and increase the rate of innovation development and therefore, the TFP growth rate (Comin, 2006). Solow (1956) originally outlined a framework that linked cross-country differences in TFP with cross-country differences in income per capita. This is confirmed in extensive research, see Klenow and Rodriguez-Clare (1997) and Hall and Jones (1999), who highlight that the majority of income differences between countries are associated to differences in TFP.

Overall, the contribution of TFP to German productivity growth is unusually small. From 1991-19956 only 15\% of German labor productivity growth originated from TFP growth; this contribution declined further to $8 \%$ by 2000-2004. The meager TFP contributions to labor productivity growth mask a dramatic underlying trend. Since 19911995, TFP growth generated by software intensive industries contributed a significant share to labor productivity growth, but at the same time, non software industries experienced increasingly negative TFP contributions. The bifurcation between software intensive and non software intensive industries in TFP is sharper than in the case of capital deepening. Negative TFP contributions from non software industries have become an ever larger drag on labor productivity, while the productivity increase generated by TFP in software intensive industries grew dramatically larger over time. By 2000-2004 software intensive industries contributed 35\% of labor productivity, while TFP non software intensive industries produced a $27 \%$ drag. The net effect is therefore a modest $8 \%$ contribution of TFP growth, all of it generated by software intensive industries.

The relationship between software intensity and TFP performance becomes especially poignant when we examine the scatter plots for labor and TFP productivity in Figures 3a)-c). They juxtapose labor productivity and total factor productivity for our three sample periods. The industry-level correlations between the two productivities are unusually high, all are greater than 0.9. This highlights the close relationship between efficiency and technological change in software intensive sectors and the labor productivity growth generated in response. 
Therefore we can establish not only an aggregate positive effect generated by software intensive industries' TFP on labor productivity, but there also seems to be a close relationship at the industry-level.

The residual labor productivity is generated by labor quality growth, which hovered around a $10 \%$ contribution and by the reallocation of hours which has been declining from about $30 \%$ to $10 \%$ from 1991-2004. Note that much of the reallocation of hours between 1991-2000 is a strong reallocation of labor towards software intensive industries. Post 2000, however, software intensive industries contracted sharply in line with the shake out one would expect of the cleaning effect of recessions proposed by Caballero and Hammour (1994). This may explain some of the increased capital deepening that software intensive industries experienced in the 2000-2004 period. Overall the results combine to clearly indicate rising capital deepening and TFP growth in software intensive sectors, and declining capital deepening and increasingly negative TFP growth in non software intensive sectors.

\section{Sources of the German Productivity Divergence}

We employ difference-in-difference regressions to quantify the divergence in TFP and labor productivity growth rates across industry types. We commence by outlining the formal framework pioneered by Stiroh (2002) and applied to Germany by Eicher and Roehn (2007). Formally, the difference-in-difference specification can be written as

$$
\Delta \ln \text { TFP }_{i, t}=\alpha+\beta \text { SOFTINTENSIVE }+\gamma \text { POST }_{T}+\delta \text { POST }_{T} \cdot S O F T I N T E N S I V E+\varepsilon_{i, t},
$$

where $\Delta \ln T F P_{i, t}$ is annual TFP productivity growth of industry $i$ in year $t, \alpha$ is a constant, SOFTINTENSIVE is a dummy variable set to 1 for software-intensive industries, and $P O S T_{T}$ is a dummy variable set to 1 for observation after year $T$ and to 0 otherwise.

The interpretation of the coefficients in this regression is as follows. $\alpha$ is the mean growth rate for non software intensive industries in the period prior to the break year. $\alpha+\beta$ is the mean growth rate for software-intensive industries prior to the break year. $\gamma$ is the acceleration for non software intensive industries after the break year, and $\gamma+\delta$ is the acceleration for software-intensive industries after the break point. $\delta$ is the differential acceleration of software-intensive industries relative to others and is the coefficient of primary interest.

Table 3 reports results that include the possibility of a post 1995 trend break. Pre 1995 non software intensive industries TFP grew by about $0.2 \%$ and there is no evidence that 
software intensive industries grew at a different rate. Post 1995 the mean growth rate of non software intensive industries declines even if the effect is not significant. This is expected since Germany experienced two successive reductions in productivity growth between 1991 and 2004 (Eicher and Roehn 2007). In contrast, software intensive industries saw a statistically significant acceleration of their TFP growth rate by 1.3 percentage points in post1995.

The additional columns in Table 3 report quantile regressions. ${ }^{7}$ Like OLS, the estimated coefficients in quantile difference-in-difference regressions can be interpreted as marginal effects. Quantiles are useful measures because they highlight long tailed distributions and potential outliers, which may be important to our investigation since we are interested in identifying exactly the contributors to productivity performance. Quantile regressions subdivide the population into quantile segments, each with equal proportions. The quantiles are then given by the data values that mark the boundaries between consecutive subsets. This approach provides richer information than ordinary least squares, which simply estimates the mean effect of a regressor, without taking into account the potential heterogeneity of industries' productivity growth rates. Changes in the mean growth rate (estimated using OLS) might be driven by only a few industries and the distribution of productivity growth might also be fundamentally different across software intensive and non software intensive industries.

Below we sketch the conditional quantile regression technique. Let $\left(y_{i}, x_{i}\right), i=1, \ldots, n$, be a sample of industry productivities from a population where $x_{i}$ is a $(K \times 1)$ vector of regressors. Assume that the $z t h$-quantile of the conditional distribution of $y_{i}$ is linear in $x_{i}$, we can write the conditional quantile regression model as

$$
y_{i}=x_{i}^{\prime} \beta_{z}+\mu_{z}
$$

Where $\mu_{z}$ is the error term. Let Quant $_{z}\left(y_{i} \mid x_{i}\right)$ denote the $z$ th-quantile of $y_{i}$, conditional on the regressor vector $x_{i}$, and let $\beta_{z}$ be the unknown vector of parameters to be estimates for different values of $z$. Then the $z$ th-quantile of the distribution $y$ for a real number $z$ with $0<\mathrm{z}<1$ can be defined as the value(s) $\bar{y}$ such that

$$
P(y \leq \bar{y}) \geq z \text { and } P(y \geq \bar{y}) \geq 1-z
$$

\footnotetext{
${ }^{7}$ Quantiles are points chosen at regular intervals from the cumulative distribution function of a random variable. For integers, the $k$ th $z$-quantile is the value $x$ such that the probability that a point chosen is less than $x$ will be at most $k / z$.
} 
This allows us to define the conditional quantile as

$$
\operatorname{Quant}_{z}\left(y_{i} \mid x_{i}\right) \equiv \inf \left\{y: F_{i}(y \mid x) \geq z\right\}=x_{i}{ }^{\prime} \beta_{z}
$$

Where Quant $_{z}\left(\mu_{z i} \mid x_{i}\right)=0$, and where $F_{i}(. \mid x)$ is the conditional distribution function of productivity growth rates.

By varying the quantile from zero to unity, we can trace the entire distribution of $y$ conditional on $x$. The estimator for the vector of parameters is obtained from

$$
\min \sum_{i=1}^{n} \rho_{z}\left(y_{i}-x_{i}{ }^{\prime} \beta_{z}\right)
$$

where $\rho_{z}(\mu)$ is a "check function" defined as

$$
\rho_{z}(\mu)=\left\{\begin{array}{cc}
z \mu & \text { if } \mu \geq 0 \\
(z-1) \mu & \text { if } \mu<0
\end{array}\right.
$$

The minimization problem is solved with linear programming techniques; see Kroenker and Basset (1978).

The quantile regressions indicate that pre 1995 TFP growth was just about identical for software intensive and non software intensive industries. This holds not only as we compare their means, but also TFP growth across the entire distribution. The major difference arises only when we examine the performance of the two industry types post 1995. Growth accelerations are uniformly negative, even for the non software intensive industries at the $95^{\text {th }}$ quantile of the TFP distribution. In contrast, productivity growth is only (insignificantly) negative for software intensive industries below the $50^{\text {th }}$-quantile. Once the median has been reached, software intensive industries' TFP growth accelerated sharply, up to 6.5\% at the $95^{\text {th }}$-quantile of the TFP distribution.

Instead of focusing on the TFP growth divergence, we can also examine the differential impact of software intensive and other industries on labor productivity growth, which we have argued to be the ultimate indicator of the standard of living. Applying the same framework as in our analysis of TFP growth, we have

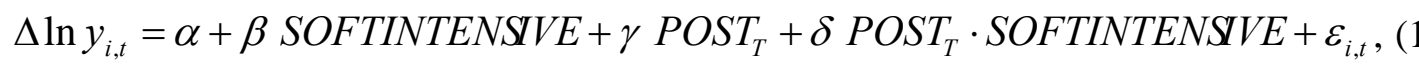


where $\Delta \ln y_{i, t}$ is annual labor productivity growth for industry $i$ in year $t$. The definitions of the variables are as in (7) and the interpretations of the parameters estimates are identical to our discussion of (7).

Table 4 reports the labor productivity results that are qualitatively similar to those in Table 3. The parameter coefficients are, however, much more precisely estimated. This allows for a distinction between software intensive and non software intensive growth rates even in the pre 1995 period. Pre 1995 non software intensive firms grew by about $2.5 \%$ while software intensive firms grew a full percentage point faster, 3.6\%. The distributional growth rates indicated by the quantile regressions show that the labor productivity distribution of the two industry types are also quite similar pre 1995.

Post 1995, labor productivity growth in non software intensive industries experienced a statistically significant decline of -1.5 percentage points to about $1 \%$, while it increased in software intensive industries by 1.4 percentage points to a strong 5\% over the $1995-2004$ period. Here we have a clear bifurcation of the fortunes of the two industry types, with one in decline and the other experiencing labor productivity growth acceleration. The quantile regressions show, however, that the acceleration was not uniform across software intensive industries. Below median productivity growth in software intensive industries is negative (although statistically insignificant) and much of this post 1995 change is driven by dramatic increases in TFP in the upper tail of the software intensive industries' TFP distribution. These industries experienced $8 \%$ and 14\% growth acceleration, respectively - in addition to their already high pre 1995 labor productivity growth.

\section{Conclusion}

In this paper we analyze the effects of the software intensity of industries on productivity growth in Germany. Software prices have fallen exponentially since 1960. This dramatic decline in costs led not only to the substitution towards more software investment, but it also increased productivity of Information and Communication Technology (ICT) hardware. ICT investment has previously been shown to be a crucial driver of productivity growth, especially in OECD countries. Previous decompositions of productivity growth focused on the contributions of aggregate ICT investment (computer, telecommunication and software). In this paper we focus on software alone. Value added shares of software and computer services are about twice as large as the computer and telecommunication hardware shares 
combined. In addition, software is the crucial interface that ultimately determines the productivity improvement of all ICT investments.

The precipitous decline in software prices has led to the continuous substitution of software and computer hardware for other types of capital or labor services. Here we use the ifo Institute Industry Growth Accounting Database that provides detailed data on software investments by industry and by software type. Our results show that software intensive industries are the crucial determinant of German productivity growth. Not only did they contribute strongly to productivity growth, but they also offset declining investments in other industries. From 1991-1995, investment in new equipment, which increased "capital deepening” (the amount of capital per worker) was about identical in software intensive and non software intensive industries. Subsequently, capital deepening in non software intensive industries collapsed to contribute only a fraction to German labor productivity growth, while investment in software intensive industries expanded to generate over half (!) of Germany’s productivity growth from 2000-2004.

Results are even more dramatic in terms of total factor productivity (TFP) growth, which is the portion of output growth commonly attributed to technical change. The overall contribution of TFP to labor productivity growth has been puzzlingly low in Germany from 1991-2004. We show that the reasons for this low contribution lie in the diverging paths of software and non software intensive industries post 1991. TFP declined consistently to generate about a 15\% drag on German labor productivity in non software intensive industries, while it rose steadily in software intensive industries to generate an unusually large, 35\%, contribution to labor productivity growth by 2000-2004. Overall the results combine to show a bifurcation of industry contributions to productivity growth. Software intensive sectors experienced rising capital deepening and TFP growth, while non software intensive sectors saw a reduction in capital labor ratios and increasingly negative TFP growth in non software intensive sectors.

Labor productivity grew significantly faster in software intensive industries, as compared to non software intensive industries. Post 1995 labor productivity growth in non software intensive industries declined by a statistically significant 1.5 percentage points while it increased in software intensive industries by 1.4 percentage points. This acceleration was not uniform across software intensive industries. Much of the growth was driven by above median software intensive industries that saw a large increase in growth of around $10 \%$. $75 \%$ 
of these contributions are generated by software investments in prepackaged software, as opposed to own account software purchases.

Finally it is important to note that our focus in this paper has been solely on software. Clearly an argument can be made that focusing on software-intensity may only provide the lower-bound of the entire German TFP growth story. If we combined the software insights with the complementarities that are achieved when software and computer investment are considered simultaneously, the heterogeneity across industries may be even more dramatic. This avenue of research is left to future research. Equally interesting are extensions that try to determine the why industries become software intensive. At this point we take their existence as given, but software intensity may well be related to import and/or export competition, unionization and or market structure. 


\section{References}

Ahmad, N. (2003), “Measuring Investment in Software”, OECD STI Working Paper, 2003/6; www.olis.oecd.org/olis/2003doc.nsf/linkto/dsti-doc(2003)

Caballero, R. and M. Hammour (1994), “The Cleansing Effect of Recessions”, American Economic Review, Vol. 84(5), pp. 1350-1368.

Comin, D. (2006), “Total Factor Productivity”, forthcoming in S. N. Durlauf and L. E. Blume, eds., The New Palgrave Dictionary of Economics, Second Edition, Palgrave Macmillan.

Eicher, T. S. and O. Roehn (2007), "Sources of the German Productivity Demise - Tracing the Effects of Industry-Level ICT Investment”, German Economic Review, Vol. 8, pp. 211-236.

Galor, O., "The Transition from Stagnation to Growth: Unified Growth Theory” in the Handbook of Economic Growth, North Holland, 2005.

Grimm, Bruce (1998), “Price Indexes for Selected Semiconductors, 1974-96.” Survey of Current Business 78 February 1998, pp. 8-24, Bureau of Economic Analysis.

Hall, R.E. and C.I. Jones (1999), "Why Do Some Countries Produce So Much More Output Per Worker Than Others?”, The Quarterly Journal of Economics, Vol. 114(1), pp. 83116.

Hermann, M. and A. Müller (1997), „Schätzung immaterieller Anlageinvestitionen in der Volkswirtschaft,“ ifo Studien zur Strukturforschung 26, ifo Institut, München.

Inklaar, Robert, Mary O’Mahony and Marcel P. Timmer (2005), “ICT and Europe’s Productivity Performance; Industry-level Growth Account Comparisons with the United States,” Review of Income and Wealth, vol. 51, no. 4, pp. 505-536.

Inklaar, Robert, Mary O’Mahony and Marcel P. Timmer (2003), “ICT and Europe’s Productivity Performance; Industry-level Growth Account Comparisons with the United States,” Research Memorandum GD 68

Jorgenson, Dale (2005), “Accounting for Growth in the Information Age”, in P. Aghion and S. N. Durlauf, eds., Handbook of Economic Growth, Volume 1A, Amsterdam, NorthHolland, pp. 743-815. 
Jorgenson, Dale W., Frank M. Gallop, and Barbara M. Fraumeni (1987), "Productivity and US Economic Growth,” Harvard University Press, Cambridge.

Jorgenson, Dale and Kevin Stiroh, (2000b), "Raising the Speed Limit: U.S. Economic Growth in the Information Age”, Brookings Papers on Economic Activity, 1, pp. 125-211.

Jorgenson, Dale W., Mun S. Ho and Kevin J. Stiroh (2005a), “Growth of US Industries and Investments in Information Technology and Higher Education,” in Carol Corrado, John Haltiwanger and Daniel Sichel (eds.) Measuring Capital in the New Economy, University of Chicago Press: Chicago.

Jorgenson, Dale W., Mun S. Ho and Kevin J. Stiroh (2005b), “Information Technology and the American Growth Resurgence,” MIT Press, Cambridge.

Jorgenson, Dale W., Mun S. Ho, Jon Samuels, and Kevin J. Stiroh (2006), “Industry Origins of the American Productivity Resurgence,” Harvard University mimeo

Jorgenson, Dale W., Mun S. Ho, Jon Samuels, and Kevin J. Stiroh (2006b), "Productivity Growth in the New Millennium and its Industry Origins” Harvard University mimeo.

Klenow, P. and A. Rodriguez-Clare (1997), "The Neo-Classical Revival in Growth Economics: Has it Gone Too Far?”, NBER Macroeconomics Annual, National Bureau of Economic Research, Cambridge, Massachusetts.

Koenker, R. and G. Basset (1978), “Regression Quantiles”, Econometrica, Vol. 46, No.1, pp. 33-50.

Lequiller, F, N. Ahmad, S. Varjonen, B. Cave and K. Ahn (2003), "Report of the OECD Taskforce on Software Measurement in the National Accounts”, OECD.

Moore, Gordon E. (1965), “Cramming More Components onto Integrated Circuits”, Electronics, 38(8), April 19, pp. 114-7.

OECD, (2000) "Software in the National Accounts: Recent Developments", Statistics Directorate, OECD.

Roehn, Oliver, Theo S. Eicher, and Thomas Strobel, (2007), "German Industry Growth Accounting Database”, CESifo Working Paper 1915.

Schreyer, Paul (2001), "Measuring Productivity: Measurement of Aggregate and IndustryLevel Productivity Growth”, OECD Manual, OECD. 
Skoczylas, Les and Bruno Tissot (2005), “Revisiting recent productivity developments across OECD countries”, BIS working papers, No. 182.

Solow, Robert M. (1956), “A Contribution to the Theory of Economic Growth”, Quarterly Journal of Economics, Vol. 70, pp. 65-94.

Stiroh, Kevin J. (2002), “Information Technology and the US Productivity Revival: What Do the Industry Data Say?” American Economic Review, vol. 92, no. 5, pp.1559-1576.

Stiroh, Kevin J. (2006), “The Industry Origins of the Second Surge of US Productivity Growth," Federal Reserve Bank of New York, mimeo.

Stiroh, Kevin and Matthew Botsch (2007), “Information Technology and Productivity Growth in the 2000s," German Economic Review, Vol. 8, pp. 255-280.

Triplett, Jack E. and Barry P. Bosworth (2004), "Productivity in the US Services Sector: New Sources of Economic Growth,” Brookings Institution Press. 


\section{Figure 1 \\ Relative Prices of Computers, Central Office Switching Equipment, and Prepackaged Software \\ 1960-2004}

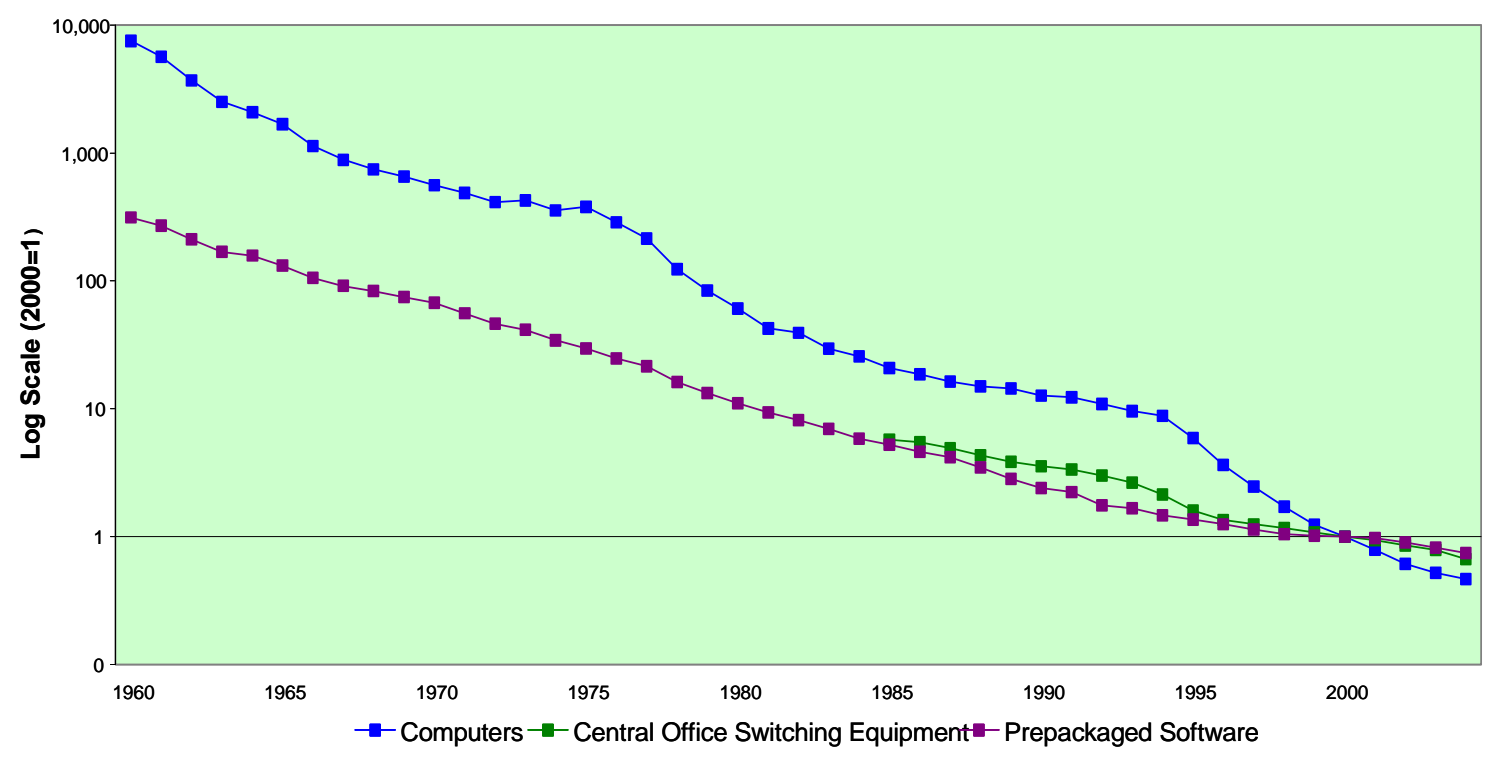

Source: Jorgenson, Ho, Samuels, and Stiroh (2006b)

Note: Price indexes are divided by the output price index.

Figure 2

Value added Shares of Information Technology by Type

1960-2004

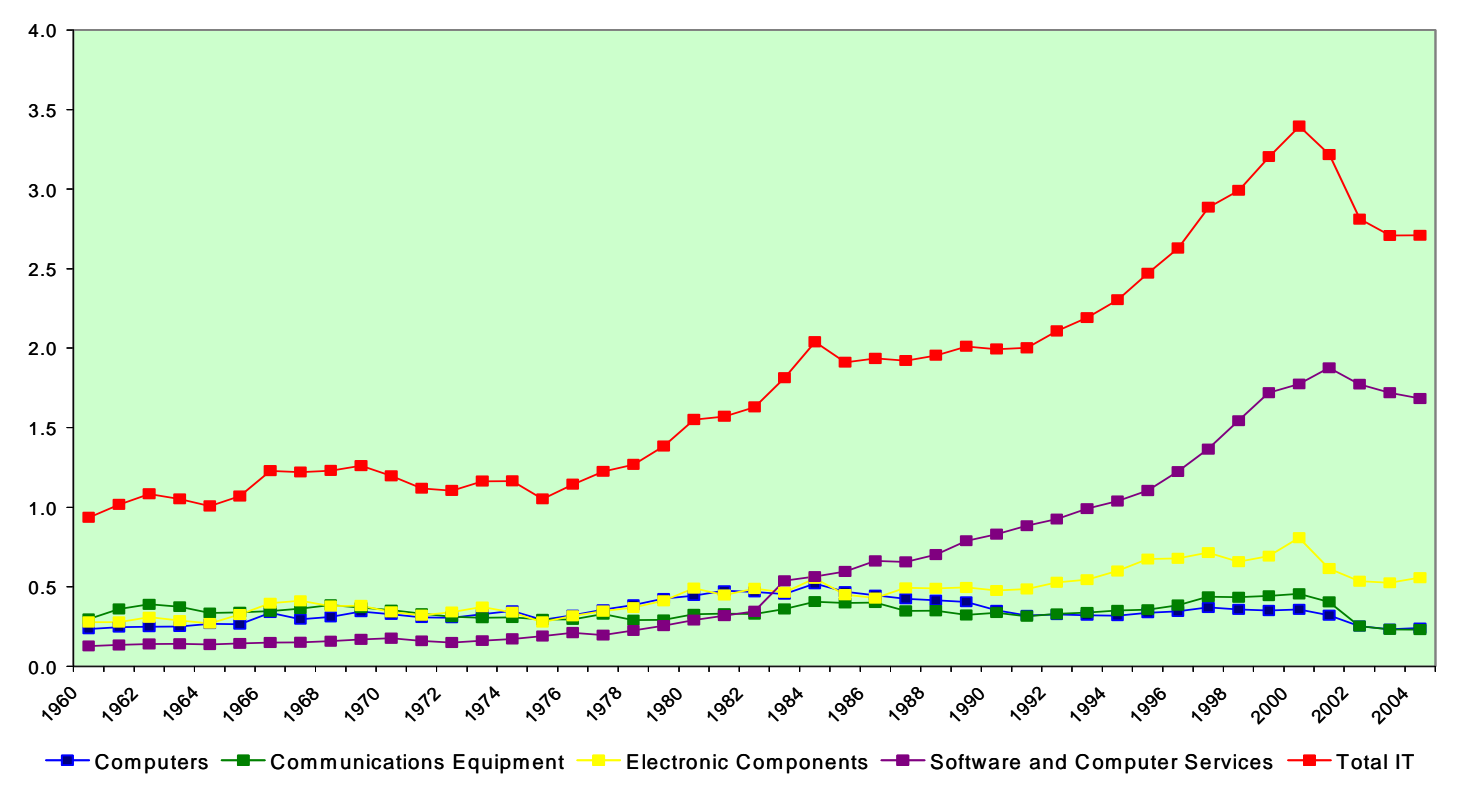

Source: Jorgenson, Ho, Samuels, and Stiroh (2006b)

Note: Share of current dollar GDP. 
Table 1

Industry Classification by Software Intensity

\begin{tabular}{|c|c|c|c|c|c|c|c|}
\hline Non-Software Intensive Industries & 91-95 & 95-00 & 00-04 & Software-Intensive Industries & 91-95 & 95-00 & 00-04 \\
\hline Agriculture, Forestry, Fishing & 0.01 & 0.02 & 0.02 & $\begin{array}{l}\text { Chemicals } \\
\text { Coke, Petroleum, Nuclear }\end{array}$ & 0.17 & 0.27 & 0.29 \\
\hline Air Transport & 0.11 & 0.15 & 0.21 & Fuels & 0.20 & 0.46 & 0.28 \\
\hline Apparel & 0.02 & 0.02 & 0.02 & $\begin{array}{l}\text { Communications } \\
\text { Computer and Related }\end{array}$ & 0.28 & 0.27 & 0.39 \\
\hline Aux. Fin. \& Ins. Intermediation & 0.08 & 0.13 & 0.16 & Activities & 0.38 & 0.75 & 1.97 \\
\hline Auxiliary Transport Activities & 0.14 & 0.21 & 0.53 & Electrical Apparatus n.e.c. & 0.25 & 0.27 & 0.29 \\
\hline Basic Metals & 0.09 & 0.13 & 0.13 & Electricity, Gas & 0.31 & 0.61 & 0.66 \\
\hline Construction & 0.08 & 0.09 & 0.09 & Financial Intermediation & 0.91 & 1.12 & 1.25 \\
\hline Education & 0.14 & 0.14 & 0.18 & Health \& Social Work & 0.25 & 0.34 & 0.43 \\
\hline Energy Mining \& Quarrying & 0.02 & 0.04 & 0.05 & Insurance & 0.99 & 1.11 & 1.24 \\
\hline Fabricated Metal Products & 0.13 & 0.15 & 0.16 & Machinery & 0.21 & 0.23 & 0.25 \\
\hline Food \& Tobacco & 0.19 & 0.15 & 0.11 & $\begin{array}{l}\text { Motor Vehicles } \\
\text { Office Machinery \& }\end{array}$ & 0.24 & 0.25 & 0.26 \\
\hline Furniture \& Manufacturing n.e.c. & 0.10 & 0.14 & 0.14 & Computers & 0.29 & 0.28 & 0.26 \\
\hline Hotels \& Restaurants & 0.01 & 0.01 & 0.01 & Other Transport Equipment & 0.28 & 0.33 & 0.35 \\
\hline Instruments & 0.09 & 0.11 & 0.13 & $\begin{array}{l}\text { Publishing, Printing } \\
\text { Radio, TV \& Comm. }\end{array}$ & 0.22 & 0.27 & 0.34 \\
\hline Land Transport & 0.00 & 0.02 & 0.07 & Equipment & 0.21 & 0.32 & 0.46 \\
\hline Leather & 0.07 & 0.06 & 0.06 & $\begin{array}{l}\text { Real Estate } \\
\text { Rec., Cultural \& Sports }\end{array}$ & 0.69 & 0.93 & 1.72 \\
\hline Mining \& Quarrying, ex. Energy & 0.03 & 0.05 & 0.04 & Activities & 0.72 & 0.94 & 1.27 \\
\hline Non-Metallic Mineral Products & 0.08 & 0.10 & 0.08 & Rental \& Leasing Services & 11.57 & 15.62 & 17.55 \\
\hline Organizations n.e.c. & 0.09 & 0.10 & 0.12 & Research and Development & 0.76 & 0.96 & 1.71 \\
\hline Other Business Services & 0.02 & 0.05 & 0.25 & Rubber, Plastic & 0.19 & 0.26 & 0.24 \\
\hline Other Services & 0.02 & 0.04 & 0.05 & Water supply & 0.93 & 1.96 & 1.89 \\
\hline Paper, Pulp & 0.13 & 0.13 & 0.16 & Water Transport & 0.94 & 1.32 & 1.86 \\
\hline Pub. Adm., Def., Soc. Security & 0.12 & 0.14 & 0.16 & Wholesale Trade & 0.35 & 0.38 & 0.45 \\
\hline Recycling & 0.16 & 0.15 & 0.13 & & & & \\
\hline Retail Trade & 0.14 & 0.17 & 0.18 & & & & \\
\hline Sale \& Repair of Motor Vehicles & 0.11 & 0.14 & 0.14 & & & & \\
\hline Sewage \& Refuse Disposal & 0.16 & 0.17 & 0.11 & & & & \\
\hline Textiles & 0.09 & 0.05 & 0.03 & & & & \\
\hline Wood Products & 0.04 & 0.08 & 0.07 & & & & \\
\hline Mean & 0.08 & 0.10 & 0.12 & Mean & 0.93 & 1.27 & 1.54 \\
\hline Median & 0.09 & 0.11 & 0.12 & Median & 0.29 & 0.38 & 0.45 \\
\hline Mean all industries & 0.46 & 0.62 & 0.75 & & & & \\
\hline Median all industries & 0.15 & 0.16 & 0.20 & & & & \\
\hline
\end{tabular}

Note: Software intensive are industries whose software capital services per hours worked exceeds the German economy median in each year from 1991-2004. 
Table 2

Source of German Labor Productivity Growth, 1991-2004

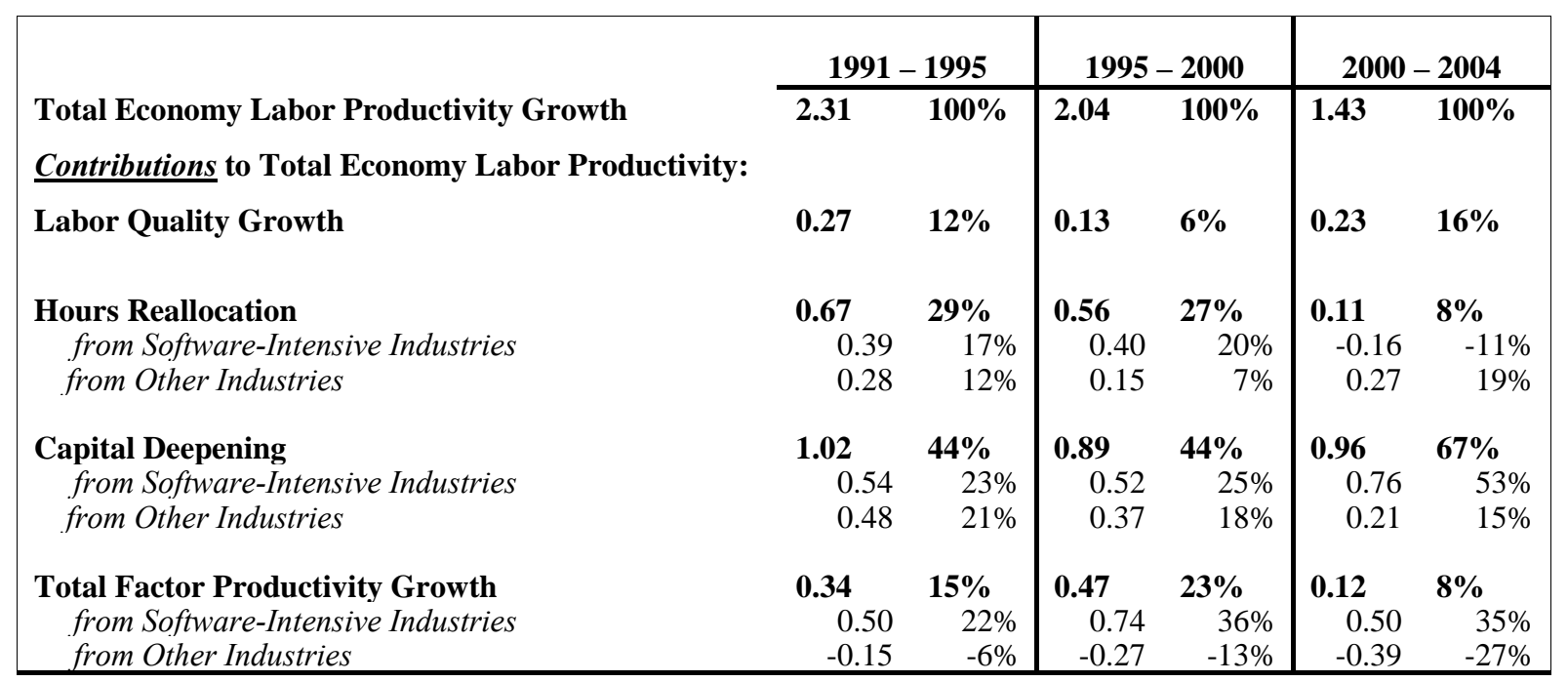

Notes: All figures are average annual percentages. The contributions of inputs are growth rates multiplied by average input shares. TFP refers to Domar-weighted TFP. Software intensive industries' software capital services share per hours worked exceed the German median from 1991-2004. Imprecise contribution aggregates stem from rounding effects. 
Figure 3a)

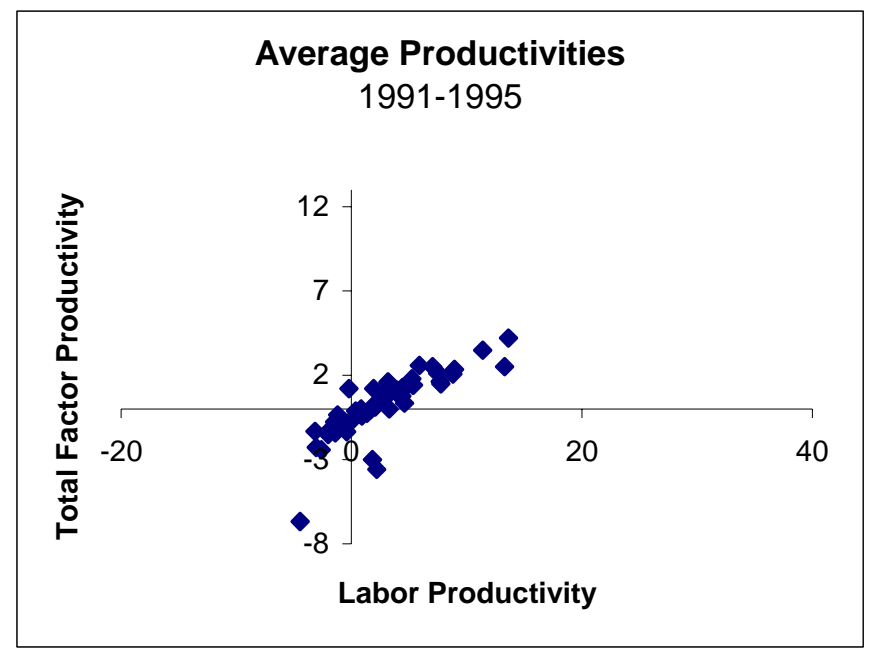

Figure 3b)

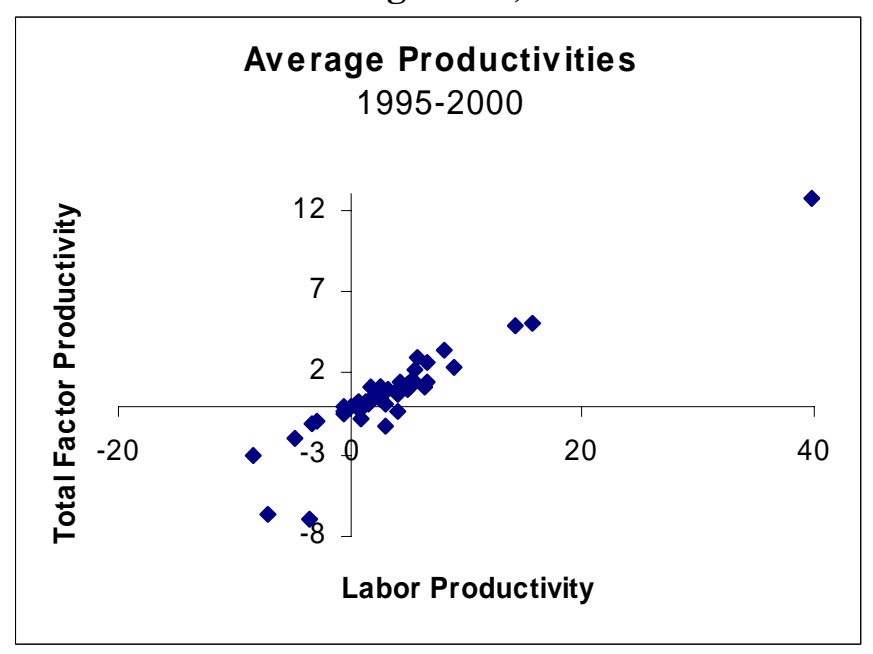

Figure 3c)

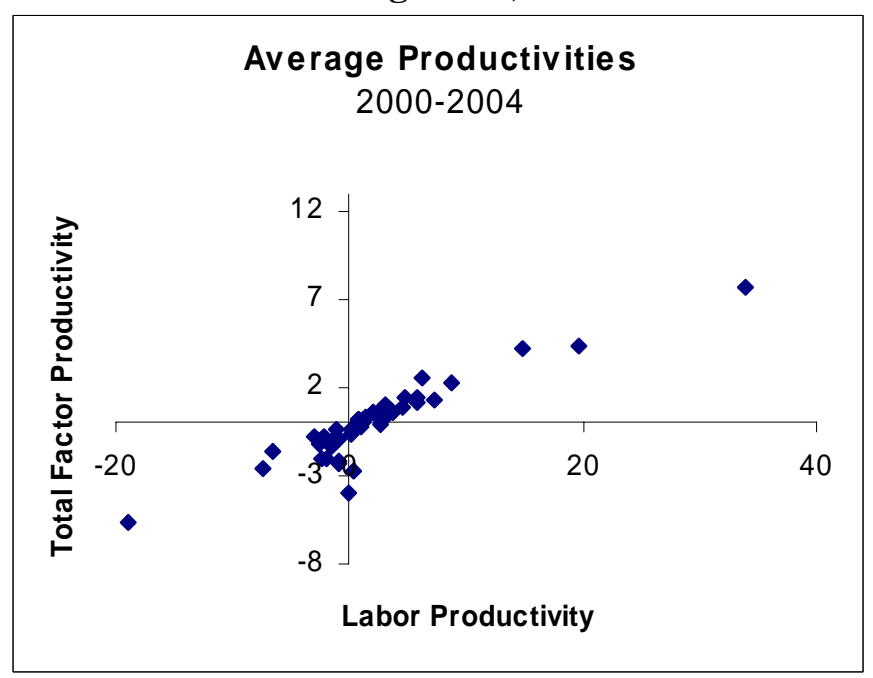


Table 3

Total Factor Productivity Growth By Industry Type (1991-2004)

\begin{tabular}{|c|c|c|c|c|c|c|c|c|}
\hline & \multicolumn{8}{|c|}{ Dependent Variable: Total Factor Productivity Growth (Value Added) } \\
\hline & \multirow{2}{*}{ OLS } & \multicolumn{7}{|c|}{ Quantile } \\
\hline & & $0.05^{\text {th }}$ & $0.10^{\text {th }}$ & $0.25^{\text {th }}$ & $0.50^{\text {th }}$ & $0.75^{\text {th }}$ & $0.90^{\text {th }}$ & $0.95^{\text {th }}$ \\
\hline $\begin{array}{l}\text { Mean growth of non software } \\
\text { intensive industries pre } 1995 \\
\text { (a) }\end{array}$ & $\begin{array}{c}0.00283 \\
{[0.00360]}\end{array}$ & $\begin{array}{c}-0.06145^{* * *} \\
{[0.01479]}\end{array}$ & $\begin{array}{c}-0.03496 * * * \\
{[0.00687]}\end{array}$ & $\begin{array}{c}-0.0114 * * * \\
{[0.00386]}\end{array}$ & $\begin{array}{c}0.00487 * \\
{[0.00254]}\end{array}$ & $\begin{array}{c}0.01909 * * * \\
{[0.00296]}\end{array}$ & $\begin{array}{c}0.0355^{* * *} \\
{[0.00873]}\end{array}$ & $\begin{array}{c}0.06479 * * * \\
{[0.01095]}\end{array}$ \\
\hline $\begin{array}{l}\text { Mean growth of software } \\
\text { intensive industries pre } 1995 \\
(\alpha+\beta)\end{array}$ & $\begin{array}{c}0.00096 \\
{[0.00464]}\end{array}$ & $\begin{array}{c}-0.06343 * * * \\
{[0.01122]}\end{array}$ & $\begin{array}{c}-0.04134^{* * *} \\
{[0.01208]}\end{array}$ & $\begin{array}{c}-0.01204 * * * \\
{[0.00407]}\end{array}$ & $\begin{array}{c}0.00451 * \\
{[0.00255]}\end{array}$ & $\begin{array}{c}0.01688 * * * \\
{[0.00431]}\end{array}$ & $\begin{array}{c}0.03798 * * * \\
{[0.00467]}\end{array}$ & $\begin{array}{c}0.04830 * * * \\
{[0.00971]}\end{array}$ \\
\hline $\begin{array}{l}\text { Growth acceleration for non } \\
\text { software intensive industries } \\
\text { post } 1995(\gamma)\end{array}$ & $\begin{array}{c}-0.00413 \\
{[0.00374]}\end{array}$ & $\begin{array}{c}0.02018 \\
{[0.01937]}\end{array}$ & $\begin{array}{c}0.00943 \\
{[0.00767]}\end{array}$ & $\begin{array}{c}0.00093 \\
{[0.00418]}\end{array}$ & $\begin{array}{c}-0.00401 \\
{[0.00307]}\end{array}$ & $\begin{array}{c}-0.00702 * * \\
{[0.00323]}\end{array}$ & $\begin{array}{c}-0.00787 \\
{[0.00940]}\end{array}$ & $\begin{array}{c}-0.02471 \\
{[0.01550]}\end{array}$ \\
\hline $\begin{array}{l}\text { Growth acceleration for } \\
\text { software intensive industries } \\
\text { post } 1995(\gamma+\delta)\end{array}$ & $\begin{array}{c}0.00904 * \\
{[0.00500]}\end{array}$ & $\begin{array}{c}0.00820 \\
{[0.01591]}\end{array}$ & $\begin{array}{c}0.00527 \\
{[0.01348]}\end{array}$ & $\begin{array}{c}0.00289 \\
{[0.00521]}\end{array}$ & $\begin{array}{c}0.00440 \\
{[0.00354]}\end{array}$ & $\begin{array}{c}0.01115^{* *} \\
{[0.00550]}\end{array}$ & $\begin{array}{c}0.03579 * * * \\
{[0.01098]}\end{array}$ & $\begin{array}{c}0.04034 * * * \\
{[0.01215]}\end{array}$ \\
\hline No. Obs. & 676 & 676 & 676 & 676 & 676 & 676 & 676 & 676 \\
\hline No. Industries & 52 & 52 & 52 & 52 & 52 & 52 & 52 & 52 \\
\hline Adj. $\mathrm{R}^{2}$ & 0.01 & --- & --- & --- & --- & --- & --- & --- \\
\hline Pseudo $\mathrm{R}^{2}$ & --- & 0.01 & 0.01 & 0.00 & 0.01 & 0.03 & 0.06 & 0.08 \\
\hline
\end{tabular}

Notes: The Post-1995 dummy equals 1 if $t>1995,0$ otherwise. The software-intensive dummy equals 1 for industries whose software capital services share per hours worked exceed the German median from 1991-2004, 0 otherwise. Quantile regressions identify the coefficients for industries at the $\mathrm{z}^{\text {th }}$-quantile percentile of the productivity distribution. All regressions are pooled regressions, standard errors in brackets. Robust standard errors were applied for OLS allowing for correlation within industries over time. Stand errors for quantile regressions are derived via bootstrap techniques for 1000 replications. Significance levels: * significant at $10 \%$; ** significant at $5 \%$; *** significant at $1 \%$. Linear composite effects are calculated using the Delta method. 


\section{Table 4}

\section{Labor Productivity Growth By Industry Type}

(1991-2004)

\begin{tabular}{|c|c|c|c|c|c|c|c|c|}
\hline & \multicolumn{8}{|c|}{ Dependent Variable: Labor Productivity Growth (Value Added) } \\
\hline & \multirow{2}{*}{ OLS } & \multicolumn{7}{|c|}{ Quantile } \\
\hline & & $0.05^{\text {th }}$ & $0.10^{\text {th }}$ & $0.25^{\text {th }}$ & $0.50^{\text {th }}$ & $0.75^{\text {th }}$ & $0.90^{\text {th }}$ & $0.95^{\text {th }}$ \\
\hline $\begin{array}{l}\text { Mean growth of non software } \\
\text { intensive industries pre } 1995 \\
\text { (a) }\end{array}$ & $\begin{array}{c}0.02528 * * * \\
{[0.00752]}\end{array}$ & $\begin{array}{c}-0.09856 * * * \\
{[0.02476]}\end{array}$ & $\begin{array}{c}-0.05565 * * * \\
{[0.01464]}\end{array}$ & $\begin{array}{c}-0.00531 \\
{[0.00832]}\end{array}$ & $\begin{array}{c}0.02385 * * * \\
{[0.00496]}\end{array}$ & $\begin{array}{c}0.06455^{* * *} \\
{[0.00778]}\end{array}$ & $\begin{array}{c}0.1072 * * * \\
{[0.01873]}\end{array}$ & $\begin{array}{c}0.15446 * * * \\
{[0.02858]}\end{array}$ \\
\hline $\begin{array}{l}\text { Mean growth of software } \\
\text { intensive industries pre } 1995 \\
(\alpha+\beta)\end{array}$ & $\begin{array}{c}0.03615 * * * \\
{[0.00884]}\end{array}$ & $\begin{array}{c}-0.05074^{* *} \\
{[0.02519]}\end{array}$ & $\begin{array}{c}-0.03551 * * * \\
{[0.01146]}\end{array}$ & $\begin{array}{c}0.00180 \\
{[0.00889]}\end{array}$ & $\begin{array}{c}0.03543^{* * *} \\
{[0.00690]}\end{array}$ & $\begin{array}{c}0.06143^{* * *} \\
{[0.01277]}\end{array}$ & $\begin{array}{c}0.11421 * * * \\
{[0.00849]}\end{array}$ & $\begin{array}{c}0.13250 * * * \\
{[0.02684]}\end{array}$ \\
\hline $\begin{array}{l}\text { Growth acceleration for non } \\
\text { software intensive industries } \\
\text { post } 1995(\gamma)\end{array}$ & $\begin{array}{l}-0.01507 * \\
{[0.00771]}\end{array}$ & $\begin{array}{c}0.02488 \\
{[0.03748]}\end{array}$ & $\begin{array}{c}0.00187 \\
{[0.01579]}\end{array}$ & $\begin{array}{c}-0.01336 \\
{[0.00946]}\end{array}$ & $\begin{array}{c}-0.01333^{* *} \\
{[0.00563]}\end{array}$ & $\begin{array}{c}-0.02402^{* *} \\
{[0.01004]}\end{array}$ & $\begin{array}{c}-0.02552 \\
{[0.02193]}\end{array}$ & $\begin{array}{c}-0.02623 \\
{[0.03420]}\end{array}$ \\
\hline $\begin{array}{l}\text { Growth acceleration for } \\
\text { software intensive industries } \\
\text { post } 1995(\gamma+\delta)\end{array}$ & $\begin{array}{c}0.01443 \\
{[0.01474]}\end{array}$ & $\begin{array}{c}-0.02899 \\
{[0.03552]}\end{array}$ & $\begin{array}{c}-0.00685 \\
{[0.01245]}\end{array}$ & $\begin{array}{c}-0.00665 \\
{[0.01005]}\end{array}$ & $\begin{array}{c}0.00013 \\
{[0.00937]}\end{array}$ & $\begin{array}{c}0.01968 \\
{[0.01435]}\end{array}$ & $\begin{array}{c}0.08004^{* *} \\
{[0.03351]}\end{array}$ & $\begin{array}{c}0.13719 * * * \\
{[0.05272]}\end{array}$ \\
\hline No. Obs. & 663 & 663 & 663 & 663 & 663 & 663 & 663 & 663 \\
\hline No. Industries & 51 & 51 & 51 & 51 & 51 & 51 & 51 & 51 \\
\hline Adj. $\mathrm{R}^{2}$ & 0.03 & --- & --- & --- & --- & --- & --- & --- \\
\hline Pseudo $\mathrm{R}^{2}$ & --- & 0.01 & 0.00 & 0.01 & 0.02 & 0.02 & 0.04 & 0.08 \\
\hline
\end{tabular}

Notes: The Post-1995 dummy equals 1 if $t>1995,0$ otherwise. The software-intensive dummy equals 1 for industries whose software capital services share per hours worked exceed the German median from 1991-2004, 0 otherwise. Quantile regressions identify the coefficients for industries at the $\mathrm{z}^{\text {th }}$-quantile percentile of the productivity distribution. All regressions are pooled regressions, standard errors in brackets. Robust standard errors were applied for OLS allowing for correlation within industries over time. Stand errors for quantile regressions are derived via bootstrap techniques for 1000 replications. Significance levels: * significant at $10 \%$; ** significant at $5 \%$; *** significant at $1 \%$. Linear composite effects are calculated using the Delta method. 
Table A1:

Industry Value added Shares, Labor Productivity, Total Factor Productivity

\begin{tabular}{|c|c|c|c|c|c|c|c|c|}
\hline \multirow{2}{*}{\multicolumn{2}{|c|}{ Industry }} & \multirow{3}{*}{$\begin{array}{c}\begin{array}{c}\text { VA Share } \\
\mathbf{2 0 0 4}\end{array} \\
11.8\end{array}$} & \multicolumn{3}{|c|}{ Labor Productivity Contributions } & \multicolumn{3}{|c|}{ TFP Contributions } \\
\hline & & & \multirow{2}{*}{$\begin{array}{c}1991- \\
1995 \\
0.00\end{array}$} & \multirow{2}{*}{$\begin{array}{c}1995- \\
2000 \\
-0.07\end{array}$} & \multirow{2}{*}{$\begin{array}{c}2000- \\
2004 \\
0.39\end{array}$} & \multirow{2}{*}{$\begin{array}{c}1991- \\
1995 \\
0.17\end{array}$} & \multirow{2}{*}{$\begin{array}{c}1995- \\
2000 \\
-0.03\end{array}$} & \multirow{2}{*}{$\begin{array}{c}2000- \\
2004 \\
0.06\end{array}$} \\
\hline Real Estate $^{\text {a) }}$ & $\mathrm{S}$ & & & & & & & \\
\hline Health \& Social Work ${ }^{\text {a) }}$ & $\mathrm{S}$ & 7.1 & 0.18 & 0.17 & 0.09 & 0.14 & 0.11 & 0.04 \\
\hline Wholesale Trade $^{\text {a) }}$ & S & 4.5 & 0.12 & 0.22 & 0.14 & 0.05 & 0.16 & 0.10 \\
\hline Financial Intermediation ${ }^{\text {a) }}$ & $\mathrm{S}$ & 3.5 & 0.06 & 0.18 & 0.11 & 0.01 & 0.12 & 0.07 \\
\hline Machinery ${ }^{\text {a) }}$ & $\mathrm{M}$ & 3.4 & 0.15 & 0.06 & 0.04 & 0.08 & 0.04 & 0.00 \\
\hline Motor Vehicles ${ }^{\text {a) }}$ & $\mathrm{M}$ & 3.2 & 0.05 & -0.09 & 0.22 & 0.00 & -0.11 & 0.16 \\
\hline Chemicals $^{\text {a) }}$ & $\mathrm{M}$ & 2.3 & 0.18 & 0.11 & 0.13 & 0.13 & 0.07 & 0.11 \\
\hline Communications ${ }^{\text {a) }}$ & $\mathrm{S}$ & 2.2 & 0.19 & 0.18 & 0.18 & 0.05 & 0.13 & 0.14 \\
\hline Rental \& Leasing Services ${ }^{\text {a) }}$ & $\mathrm{S}$ & 1.9 & 0.03 & 0.05 & 0.00 & -0.05 & -0.02 & -0.07 \\
\hline Rec., Cultural \& Sports Activities ${ }^{\text {a) }}$ & $\mathrm{S}$ & 1.8 & -0.01 & 0.02 & -0.05 & -0.04 & 0.00 & -0.07 \\
\hline Electricity, Gas ${ }^{\text {a) }}$ & M & 1.8 & 0.09 & 0.17 & 0.04 & 0.01 & 0.08 & 0.03 \\
\hline Electrical Apparatus n.e.c. $^{\text {a) }}$ & $\mathrm{M}$ & 1.6 & 0.04 & 0.08 & 0.01 & 0.00 & 0.06 & 0.00 \\
\hline Computer and Related Activities ${ }^{\text {a) }}$ & $\mathrm{S}$ & 1.5 & -0.01 & 0.03 & -0.02 & -0.03 & 0.00 & -0.05 \\
\hline Rubber, Plastic ${ }^{\text {a) }}$ & $\mathrm{M}$ & 1.1 & 0.03 & 0.02 & 0.03 & 0.02 & 0.02 & 0.02 \\
\hline Publishing, Printing ${ }^{\text {a) }}$ & $\mathrm{M}$ & 1.1 & 0.01 & 0.05 & -0.01 & -0.01 & 0.03 & -0.03 \\
\hline Insurance $^{\text {a) }}$ & $\mathrm{S}$ & 0.9 & 0.04 & -0.08 & -0.14 & 0.02 & -0.09 & -0.15 \\
\hline Radio, TV \& Comm. Equipment ${ }^{\text {a) }}$ & $\mathrm{M}$ & 0.6 & 0.05 & 0.04 & 0.08 & 0.03 & 0.03 & 0.06 \\
\hline Other Transport Equipment ${ }^{\text {a) }}$ & $\mathrm{M}$ & 0.4 & -0.01 & 0.05 & 0.02 & -0.02 & 0.05 & 0.01 \\
\hline Research and Development ${ }^{\text {a) }}$ & $\mathrm{S}$ & 0.4 & 0.01 & 0.02 & -0.01 & 0.01 & 0.02 & -0.01 \\
\hline Water Transport ${ }^{\text {a) }}$ & $\mathrm{S}$ & 0.3 & 0.02 & 0.03 & 0.05 & 0.01 & 0.02 & 0.04 \\
\hline Coke, Petroleum, Nuclear Fuels ${ }^{\text {a) }}$ & M & 0.2 & -0.06 & -0.02 & -0.01 & -0.07 & -0.02 & 0.00 \\
\hline Office Machinery \& Computers ${ }^{\text {a) }}$ & $\mathrm{M}$ & 0.2 & 0.04 & 0.09 & 0.06 & 0.02 & 0.09 & 0.06 \\
\hline Water supply $^{\text {a) }}$ & M & 0.2 & 0.01 & 0.01 & 0.01 & -0.01 & 0.00 & 0.00 \\
\hline Other Business Services $^{\text {b) }}$ & $\mathrm{S}$ & 8.6 & -0.09 & -0.39 & -0.22 & -0.09 & -0.45 & -0.25 \\
\hline Pub. Adm.., Def., Soc. Security b) & $\mathrm{S}$ & 6.1 & 0.20 & 0.11 & 0.07 & 0.09 & 0.02 & -0.02 \\
\hline Education ${ }^{\text {b) }}$ & $\mathrm{S}$ & 4.5 & 0.01 & 0.02 & -0.09 & -0.01 & 0.00 & -0.10 \\
\hline Retail Trade $^{\text {b) }}$ & $\mathrm{S}$ & 4.2 & 0.00 & 0.05 & 0.03 & -0.05 & 0.02 & 0.01 \\
\hline Construction $^{b)}$ & $\mathrm{M}$ & 4.2 & -0.10 & 0.00 & 0.04 & -0.13 & -0.01 & 0.03 \\
\hline Fabricated Metal Products ${ }^{b}$ & $\mathrm{M}$ & 2.0 & 0.02 & 0.07 & 0.02 & -0.01 & 0.05 & 0.01 \\
\hline Food \& Tobacco ${ }^{b)}$ & $\mathrm{M}$ & 2.0 & -0.02 & 0.01 & -0.06 & -0.06 & 0.02 & -0.06 \\
\hline Sale \& Repair of Motor Vehicles ${ }^{\text {b) }}$ & $\mathrm{S}$ & 1.8 & -0.04 & 0.01 & 0.01 & -0.06 & 0.00 & 0.00 \\
\hline Auxiliary Transport Activities ${ }^{\text {b) }}$ & $\mathrm{S}$ & 1.6 & 0.05 & 0.03 & 0.06 & 0.03 & 0.02 & 0.02 \\
\hline Hotels \& Restaurants ${ }^{\text {b) }}$ & $\mathrm{S}$ & 1.6 & -0.03 & -0.01 & -0.02 & -0.04 & -0.01 & -0.03 \\
\hline Land Transport $^{\mathrm{b})}$ & $\mathrm{S}$ & 1.4 & 0.11 & 0.02 & 0.00 & 0.06 & -0.02 & -0.02 \\
\hline Other Services $^{\text {b) }}$ & $\mathrm{S}$ & 1.4 & 0.02 & -0.01 & -0.03 & 0.00 & -0.02 & -0.04 \\
\hline Agriculture, Forestry, Fishing b) & $\mathrm{A}$ & 1.2 & 0.06 & 0.07 & 0.07 & 0.02 & 0.05 & 0.06 \\
\hline Basic Metals b) & $\mathrm{M}$ & 0.9 & 0.09 & 0.04 & 0.01 & 0.06 & 0.04 & 0.00 \\
\hline Instruments ${ }^{\text {b) }}$ & $\mathrm{M}$ & 0.9 & 0.01 & 0.05 & 0.01 & 0.00 & 0.04 & 0.00 \\
\hline Organizations n.e.c. $^{\text {b) }}$ & $\mathrm{S}$ & 0.8 & 0.01 & 0.01 & 0.00 & 0.01 & 0.01 & 0.00 \\
\hline Non-Metallic Mineral Products ${ }^{\text {b) }}$ & M & 0.7 & 0.06 & 0.02 & 0.01 & 0.04 & 0.01 & 0.01 \\
\hline Aux. Fin. \& Ins. Intermediation b) & $\mathrm{S}$ & 0.7 & -0.01 & -0.02 & 0.03 & -0.02 & -0.02 & 0.03 \\
\hline Sewage \& Refuse Disposal ${ }^{b)}$ & $\mathrm{S}$ & 0.7 & -0.03 & -0.03 & -0.01 & -0.07 & -0.07 & -0.02 \\
\hline Furniture \& Manufacturing n.e.c. ${ }^{\text {b) }}$ & $\mathrm{M}$ & 0.5 & -0.01 & 0.02 & -0.01 & -0.03 & 0.01 & -0.01 \\
\hline Paper, Pulp ${ }^{\text {b) }}$ & $\mathrm{M}$ & 0.5 & 0.00 & 0.03 & 0.01 & -0.01 & 0.02 & 0.00 \\
\hline Wood Products ${ }^{\text {b) }}$ & M & 0.4 & 0.02 & 0.02 & 0.00 & 0.02 & 0.01 & 0.00 \\
\hline Air Transport ${ }^{\text {b) }}$ & $\mathrm{S}$ & 0.3 & 0.04 & 0.02 & -0.01 & 0.03 & 0.01 & -0.01 \\
\hline Textiles ${ }^{b)}$ & $\mathrm{M}$ & 0.2 & 0.02 & 0.01 & 0.01 & 0.00 & 0.01 & 0.01 \\
\hline Apparel b) & $\mathrm{M}$ & 0.1 & 0.01 & 0.01 & 0.01 & 0.01 & 0.01 & 0.01 \\
\hline Mining \& Quarrying, ex. Energy b) & $\mathrm{M}$ & 0.1 & 0.02 & 0.00 & -0.01 & 0.01 & 0.00 & -0.01 \\
\hline Energy Mining \& Quarrying b) & $\mathrm{M}$ & 0.1 & 0.04 & -0.02 & 0.00 & 0.02 & -0.02 & 0.00 \\
\hline Recycling $^{b)}$ & $\mathrm{M}$ & 0.1 & 0.00 & 0.00 & 0.00 & 0.00 & 0.00 & 0.00 \\
\hline Leather ${ }^{\text {b) }}$ & $\mathrm{M}$ & 0.1 & 0.01 & 0.00 & 0.00 & 0.00 & 0.00 & 0.00 \\
\hline
\end{tabular}

Notes: a) Software-intensive industry, b) Other industry, $\mathrm{M}=$ Manufacturing industries, $\mathrm{S}=$ Services sectors. Average annual percentages. ALP contributions are labor productivity growth rates multiplied by average value- added shares. Contributions of TFP are industry TFP growth rates multiplied by industry output share in aggregate value added (Domarweight). Software intensive industries' software capital services share per hours worked exceed the German median from 1991-2004. 